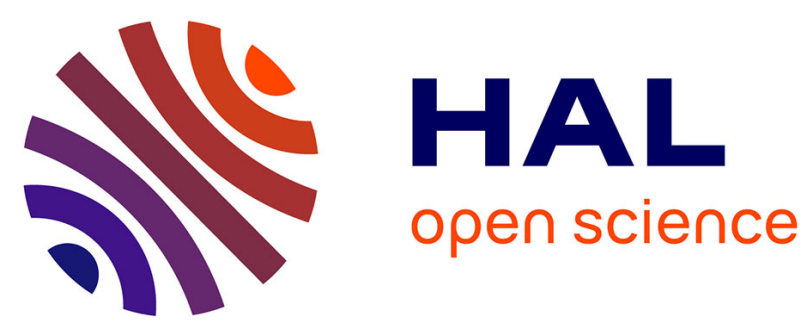

\title{
A biodynamic model predicting waterborne lead bioaccumulation in Gammarus pulex: Influence of water chemistry and in situ validation
}

N. Urien, E. Uher, E. Billoir, Olivier Geffard, L.C. Fechner, J.D. Lebrun

\section{- To cite this version:}

N. Urien, E. Uher, E. Billoir, Olivier Geffard, L.C. Fechner, et al.. A biodynamic model predicting waterborne lead bioaccumulation in Gammarus pulex: Influence of water chemistry and in situ validation. Environmental Pollution, 2015, 203, pp.22-30. 10.1016/j.envpol.2015.03.045 . hal-01153660

\author{
HAL Id: hal-01153660 \\ https://hal.science/hal-01153660
}

Submitted on 20 May 2015

HAL is a multi-disciplinary open access archive for the deposit and dissemination of scientific research documents, whether they are published or not. The documents may come from teaching and research institutions in France or abroad, or from public or private research centers.
L'archive ouverte pluridisciplinaire HAL, est destinée au dépôt et à la diffusion de documents scientifiques de niveau recherche, publiés ou non, émanant des établissements d'enseignement et de recherche français ou étrangers, des laboratoires publics ou privés. 


\title{
A biodynamic model predicting waterborne lead bioaccumulation in Gammarus pulex: Influence of water chemistry and in situ validation
}

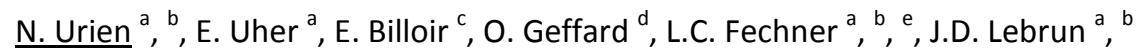 \\ ${ }^{a}$ Irstea, UR HBAN - Ecotoxicology, 1 rue Pierre-Gilles de Gennes, CS 10030, F-92761 Antony Cedex, France \\ ${ }^{\mathrm{b}}$ FIRE FR-3020, 4 place Jussieu, 75005 Paris, France \\ ' Universit_e de Lorraine, CNRS UMR 7360, Laboratoire Interdisciplinaire des Environnements Continentaux \\ (LIEC), Metz, France \\ ${ }^{\mathrm{d}}$ Irstea, UR MAEP, Freshwater Systems, Ecology and Pollution, 5 rue de la Doua, CS 70077, F-69626 \\ Villeurbanne Cedex, France \\ e AgroParisTech, 19 Avenue du Maine, F-75732 Paris Cedex 15, France
}

Keywords: Pb; Gammarid; Waterborne exposure; Water chemistry; Metal bioavailability; Toxicokinetics

\begin{abstract}
Metals bioaccumulated in aquatic organisms are considered to be a good indicator of bioavailable metal contamination levels in freshwaters. However, bioaccumulation depends on the metal, the species, and the water chemistry that influences metal bioavailability. In the laboratory, a kinetic model was used to describe waterborne $\mathrm{Pb}$ bioaccumulated in Gammarus pulex. Uptake and elimination rate constants were successfully determined and the effect of $\mathrm{Ca}^{2+}$ on $\mathrm{Pb}$ uptake was integrated into the model. Thereafter, accumulated $\mathrm{Pb}$ concentrations in organisms were predicted with the model and compared with those measured in native populations from the Seine watershed (France). The predictions had a good agreement with the bioaccumulation levels observed in native gammarids and particularly when the effect of calcium was considered. To conclude, kinetic parameters experimentally derived for $\mathrm{Pb}$ in $\mathrm{G}$. pulex are applicable in environmental conditions. Moreover, the consideration of the water's chemistry is crucial for a reliable interpretation of bioaccumulation.
\end{abstract}

\section{Introduction}

Trace metals naturally occur in the environment but human activities have largely contributed to their release in continental waters. Among trace metals, lead $(\mathrm{Pb})$ is rightly considered within the European Water Framework Directive (WFD) as a priority substance (Directive, 2000/60/EC). Indeed, this metal is one of the most important trace metal contaminants occurring in the aquatic environment as a consequence of both natural and anthropogenic processes, i.e. mining, coal burning, cement manufacturing, and traffic (Kutlu et al., 2002; WHO, 1995). Moreover, $\mathrm{Pb}$ is nonessential for biological processes and may cause damage to aquatic organisms even at very low concentrations. For example, studies reported reproductive effects in rainbow trout and Daphnia magna or behavioural disorders in fish and snails after chronic exposure to Pb (Berglin et al., 1985; Holcombe et al., 1976; Pyatt et al., 2002; Ruby et al., 2000).

Chemical analyses of dissolved metal concentrations are recommended by the WFD to monitor metal contamination in river water. Nevertheless, this approach gives a pointwise picture of the metal contamination in the environment and does not give information on bioavailable metals, which are the fraction of metals able to interact with organisms and potentially exert toxicity. Moreover, bioavailability is strongly affected by the geochemistry conditions. As a consequence, chemical analyses of environmental compartments, such as the water, sediment, are not sufficient for diagnosing the impact of metallic contamination on aquatic biota. Alternatively, the quantification of metal concentrations accumulated in aquatic organisms gives an integrated measure of their exposure and includes the effect of water chemistry on dissolved metal bioavailability. Thus, 
bioaccumulation of metals in aquatic species has been successfully used to assess spatial and temporal trends of bioavailable metals in continental waters (Baudrimont et al., 1999; Besse et al., 2012; Chevreuil et al., 1996).

Among the aquatic organisms predisposed to monitor trends of bioavailable metal contamination in the freshwaters, the amphipods of the genus Gammarus arouse interest as they are widespread and ubiquitous in rivers and streams of Europe, where they are often present in high density. Gammarids are also of ecological relevance as they actively contribute to the leaf litter breakdown and represent a good source of food for predators like birds, fish, amphibians (Forrow and Maltby, 2000; Graça et al., 2001; Welton, 1979). Moreover, gammarids are known to be net accumulators of various metals, essential or not, and are therefore considered as promising species to monitor metal bioavailability in freshwaters (Felten et al., 2008; Fialkowski and Rainbow, 2006; Lebrun et al., 2012, 2014).

The link between metal contamination in the water and bioaccumulation in organisms is not straightforward. Today, biodynamic modelling is a common approach used to describe metal bioaccumulation in aquatic organisms (Bourgeault et al., 2010; Casado-Martinez et al., 2009; Cresswell et al., 2014; Kalman et al., 2010; Lebrun et al., 2012; Luoma and Rainbow, 2005). The biodynamic model assumes that bioaccumulation is the result of a balance between the uptake rates, from aqueous and dietary routes, and loss rates (Luoma and Rainbow, 2005). While it is likely to be significant, the relative importance of the diet to total metal uptake is still to be determined for many freshwater invertebrates under specific exposure conditions, including the case of $\mathrm{Pb}$ accumulation by Gammarus pulex. It is still relevant, therefore, to investigate $\mathrm{Pb}$ accumulation by this amphipod after uptake from solution alone, in order to assess the significance of this waterborne source to total lead accumulation. During waterborne exposures, metal fluxes depend on kinetic parameters, the uptake and the elimination rate constants, which are specific to the metal/organism couple and which can be determined under laboratory conditions. Nonetheless, studies about kinetics of $\mathrm{Pb}$ uptake are limited unlike $\mathrm{Cd}, \mathrm{Zn}, \mathrm{Cu}$ or $\mathrm{Ni}$, which have been widely investigated in freshwater invertebrates, including Gammarus species (Lebrun et al., 2012, 2011; Pellet et al., 2009; Xu and Pascoe, 1993). Indeed, in freshwater macroinvertebrates, bioaccumulation kinetic parameters of $\mathrm{Pb}$ have been determined for $D$. magna (Komjarova and Blust, 2009) or the amphipod Hyalella azteca (MacLean et al., 1996). To our knowledge no kinetic models have been developed for Pb in gammarids (Lebrun et al., 2011, 2012; Pellet et al., 2009, 2014). Furthermore, there is a relative lack of information on the modelling of $\mathrm{Pb}$ bioaccumulation by freshwater invertebrates, especially because of the lack of suitable radioisotopes for $\mathrm{Pb}$, and because of limited access to suitable alternative stable isotope measurement facilities.

Water chemistry has often been pointed out as influencing the bioavailability of metals. In the literature, it is well accepted that the main soluble metal forms suggested as bioavailable are free ions (Di Toro et al., 2001; Morel, 1983). Indeed, metallic ions can directly interact with the biological binding sites of aquatic organisms (Niyogi and Wood, 2004). Major ions present in the water, such as calcium $\left(\mathrm{Ca}^{2+}\right)$, magnesium $\left(\mathrm{Mg}^{2+}\right)$ or sodium $\left(\mathrm{Na}^{+}\right)$, have the potential to interact with free metal ions on biological surfaces and consequently modulate metal bioavailability. For example, different studies have reported the decrease of $\mathrm{Pb}$ accumulation with increasing $\mathrm{Ca}^{2+}$ in many species including crustaceans (Besser et al., 2005; Komjarova and Blust, 2009), fish (Grosell et al., 2006; Macdonald et al., 2002) or algae (Slaveykova and Wilkinson, 2002). Such an effect of Ca ${ }^{2+}$ on $\mathrm{Cd}$ and $\mathrm{Ni}$ uptake has also been reported in various aquatic species (Croteau and Luoma, 2007; Keithly et al., 2004; Kienle et al., 2009; Tan and Wang, 2008) including G. pulex (Lebrun et al., 2011; Pellet et al., 2009). Taking into account water's cationic composition could be a way to improve metal bioaccumulation modelling and to better interpret bioaccumulation in terms of bioavailable contamination (Bourgeault et al., 2010; Pellet et al., 2009).

The aim of this study was to calibrate, under laboratory conditions, a kinetic model predicting waterborne metal bioaccumulation in G. pulex. The influence of water's cationic composition on $\mathrm{Pb}$ uptake was also investigated. Finally, the question of the applicability of the model to estimate bioaccumulation of $\mathrm{Pb}$ in situ was addressed. To this end, calibrated G. pulex were independently exposed to different Pb concentrations in controlled conditions (from $1 \mathrm{mg} \mathrm{L}^{-1}$ to $100 \mathrm{mg} \mathrm{L}^{-1}$ ). The concentration of $\mathrm{Pb}$ in organisms was measured over time for the determination of kinetic parameters. Then, gammarids were exposed to $\mathrm{Pb}$ in media exhibiting different concentrations of $\mathrm{Ca}^{2+}, \mathrm{Na}^{+}$, or $\mathrm{Mg}^{2+}$ in order to evaluate their influence on $\mathrm{Pb}$ uptake. Finally, 
predictions made by the model taking into account the effect of calcium or not were compared to the contamination levels of native $G$. pulex collected at the Seine watershed (France).

\section{Materials and methods}

\subsection{Experimental design}

\subsubsection{Collection and maintenance of G. pulex}

Adult G. pulex were collected in February 2012 in a river (Ru de l'Etang, Doue, France) where the dissolved concentrations for several metals were overall below world average values in uncontaminated rivers (Gaillardet et al., 2003) and below the Environmental Quality Standard (EQS) recommended by the WFD for metals belonging to the list of priority substances (Directive, 2013/39/EC). Gammarids were sieved (between meshsize of 2 and $2.5 \mathrm{~mm}$ ) to collect only adult individuals (length of about $1 \mathrm{~cm}$ for a width between 2 and $2.5 \mathrm{~mm}$ ), transported to the laboratory, and then acclimatised for 7 days at $14{ }^{\circ} \mathrm{C}$ in aerated mineral water $\left(\mathrm{Volvic}^{\otimes} \mathrm{Ca}^{2+}\right.$ 11.5, $\mathrm{Na}^{+} 11.6, \mathrm{Mg}^{2+} 8.0, \mathrm{~K}^{+} 6.2, \mathrm{Cl}^{-} 13.5, \mathrm{SO}_{4}{ }^{2-} 8.1 \mathrm{mg} \mathrm{L}^{-1}$ and $\mathrm{pH}$ 7) with a 10:14-h light:dark photoperiod. Organisms were fed ad libitum with hornbeam leaves (Carpinus betulus) from the same sampling site.

\subsubsection{Kinetics of bioaccumulation}

Aquatic microcosms created in plastic beakers were filled with $500 \mathrm{~mL}$ of Volvic ${ }^{\circledast}$ mineral water and spiked with $\mathrm{Pb}\left(\mathrm{NO}_{3}\right)_{2}$ so as to obtain final $\mathrm{Pb}$ exposure concentrations of $1,2.5,5,10,25,50$, and $100 \mathrm{mg} \mathrm{L}^{-1}$. The range of $\mathrm{Pb}$ concentrations chosen for the exposures was made to be approximately between EQS/10 and EQS*10 i.e. from 1 to $100 \mathrm{mg} \mathrm{L}^{-1}$ (EQS $=7.2 \mathrm{mg} \mathrm{L}^{-1}$ (Directive, 2008/105/EC)). Each condition was performed in triplicates of microcosms, which were pre-equilibrated for $48 \mathrm{~h}$ to saturate the potential adsorption sites before performing the experiment in order to ensure a constant metal exposure. Then, fifty 24-h-starved G. pulex were introduced in each beaker without food for 5 days of exposure followed by a 7-day depuration period. During the exposure phase, each medium was renewed every day to ensure a constant exposure and a correct oxygenation rate. During the depuration period, each beaker was renewed only with uncontaminated Volvic ${ }^{\circledR}$ mineral water and gammarids could feed ad libitum on hornbeam leaves. A pool of five gammarids per beaker was sampled on day $0,0.5,1,2$, and 5 for the exposure phase and on day 7,9 , and 12 for the depuration phase. Each time, gammarids were rinsed in a solution of 2 and then $0.5 \mathrm{mM} \mathrm{EDTA}$, and then rinsed twice with ultrapure water to remove metal potentially adsorbed on their cuticle (Lebrun et al., 2011) and stored at $-20^{\circ} \mathrm{C}$. At the same time, dead gammarids were counted and removed. At each sampling time, renewed water was sampled and the water contamination level was checked for $\mathrm{Pb}$ using a graphite furnace atomic absorption spectrophotometer (AAS; SpectrAA $220 Z$ Varian with Zeeman background correction).

For analysis, gammarids were freeze-dried (Christ Alpha 2-4 LD plus), weighed, and digested at $95{ }^{\circ} \mathrm{C}$ (Digiprep Jr, SCP Science) with $\mathrm{HNO}_{3}$ (65\% suprapur, Merck), $\mathrm{H}_{2} \mathrm{O}_{2}$ (suprapur, Merck), and finally diluted with ultrapure water. $\mathrm{Pb}$ analysis in gammarids was performed by AAS in standard addition to limit matrix effects. Calibration was performed after every three samples. The quality of the analysis of waters has been checked by analysing two natural water certified reference materials every 20 samples (SPS-SW1, Spectrapure standard AS Oslo and EP-L-2CR, EnviroMAT). The quality of the whole analysis process of gammarids including digestion has been checked by analysing the two natural water certified reference materials cited above every 20 samples, and a certified reference material of biological tissue (CMR: Mussel Tissue ERM-CE278). The mean of every certified material was consistently within the certified $95 \%$ confidence limit range for $\mathrm{Pb}$.

In this study, every unit related to the mass of gammarids is expressed in dry weight.

The background $\mathrm{Pb}$ concentration in control organisms was determined to be $0.64 \pm 0.23 \mu \mathrm{g} \mathrm{g}^{-1}(n=12)$. This value was subtracted from all subsequent tissue $\mathrm{Pb}$ measurements to determine the net accumulated $\mathrm{Pb}$ from the exposure.

\subsubsection{Influence of major ions on $\mathrm{Pb}$ uptake}

To assess the influence of major cations on metal uptake, gammarids were exposed for 2 days to $10 \mathrm{mg} \mathrm{L}^{-1}$ of $\mathrm{Pb}$ in Volvic ${ }^{\circledR}$ microcosms (plastic beakers of $500 \mathrm{~mL}$ ) containing 30, 60, and $100 \mathrm{mg} \mathrm{L-1}$ of $\mathrm{Na}^{+}$or Mg$^{2+}$ or 25 , $50,75,100$, and $150 \mathrm{mg} \mathrm{L}^{-1}$ of $\mathrm{Ca}^{2+}$ obtained by adding solutions of $\mathrm{NaNO}_{3}, \mathrm{Mg}\left(\mathrm{NO}_{3}\right) \cdot 6 \mathrm{H}_{2} \mathrm{O}$ or $\mathrm{CaCl}_{2}$ to the 
starting Volvic ${ }^{\circledast}$ medium. The ranges of cation concentrations are of environmental relevance since they have been chosen in accordance with the ranges found in the Seine watershed from the Agence de l'Eau de SeineNormandie public database (http://www.eau-seine-normandie.fr/). Each condition was performed in triplicate and all microcosms were pre-equilibrated for $48 \mathrm{~h}$ before the experiment. Then, ten 24 -h-starved G. pulex were introduced in each beaker without food for 2 days of exposure. Each medium was renewed on day 1 to ensure a constant exposure. After 2 days, a pool of five gammarids per beaker was sampled, rinsed, digested, and analysed for $\mathrm{Pb}$ by $\mathrm{AAS}$ as described in Section 2.1.2. Cationic concentrations in media were determined via chromatographic analysis [Dionex DX120, column lonPac CS16 Dionex N057573 (4 x $250 \mathrm{~mm}$ )] and Pb exposure was analysed by AAS. An exposure concentration equal to $10 \mathrm{mg} \mathrm{L}^{-1}$ of $\mathrm{Pb}$ was chosen because it was the most appropriate concentration to observe a significant accumulation after 2 days of exposure and to stay in agreement with the EQS defined by the WDF before 2013 (EQS $=7.2 \mathrm{mg} \mathrm{L}^{-1}$ (Directive, 2008/105/EC)).

\subsection{Field data}

Sampling of native G. pulex from 21 sites from the Seine watershed was performed, among which 14 were sampled in 2008, three in 2009, two in 2012, and two in 2013 (Fig. 1). Collection sites are characterised by various anthropogenic pressures and contrasted water chemistry (Lebrun et al., 2014; Tusseau-Vuillemin et al., 2007). At each site, 50 adult gammarids were collected (for a resulting length of $1 \mathrm{~cm}$, as described in 2.1.1), transported to the laboratory in plastic bottles containing river water, and identified according to a reference taxonomic determination. Then, collected gammarids were distributed in triplicates of 10 individuals in $50-\mathrm{mL}$ polypropylene tubes (SCP Science), treated as described in Section 2.1.2, and analysed by inductively coupled plasma mass spectrometry (ICP-MS, $X$ series 2, Thermo Fisher Scientific) to determine their $\mathrm{Pb}$ content in tissues.

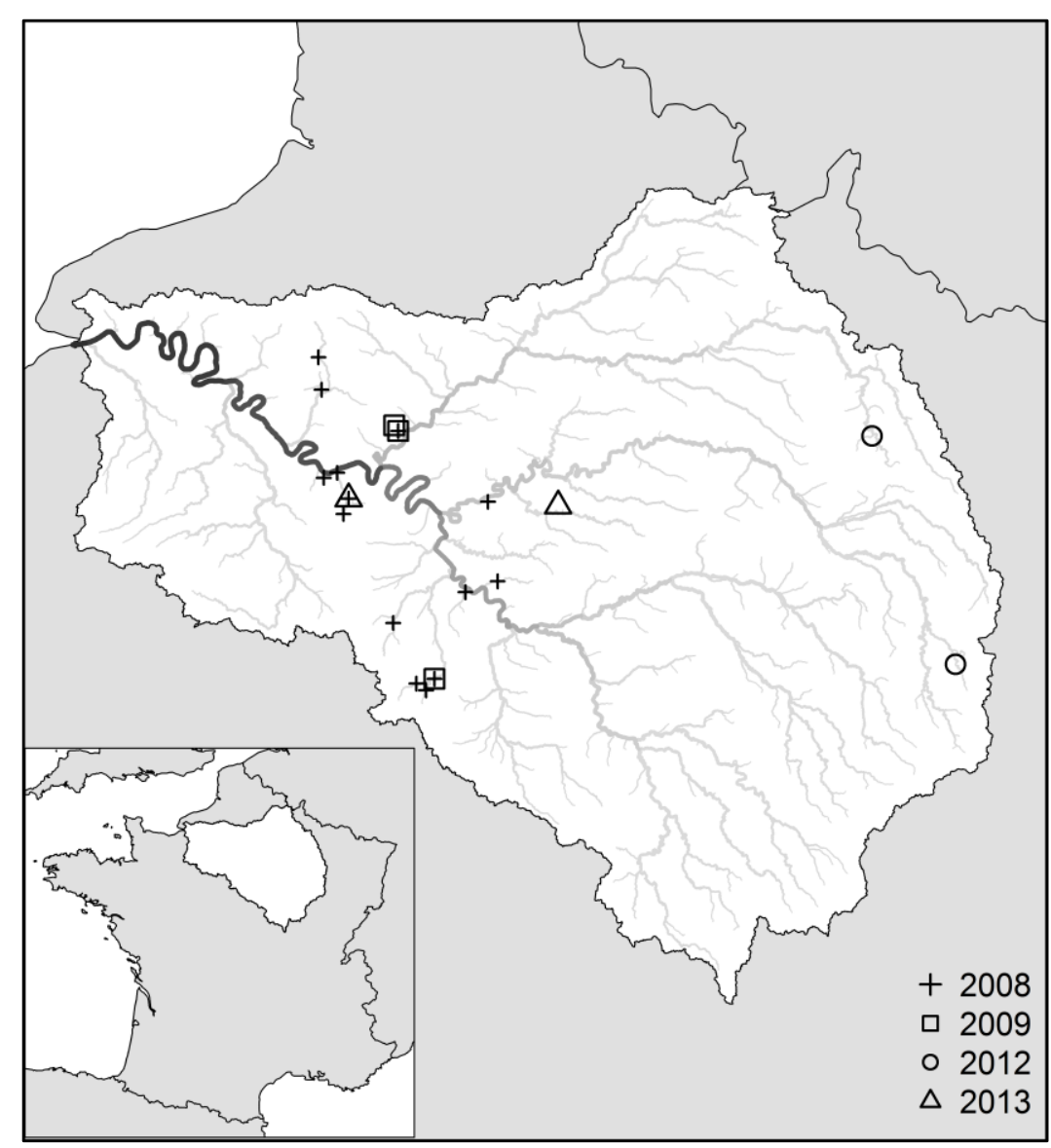

Fig. 1. Twenty one sites at the Seine watershed in France where native gammarids were collected for $\mathrm{Pb}$ contents analyses. Sampling consisted in collecting three replicates of five calibrated adult individuals $(n=3)$. Each symbol corresponds to a sampling year. 
River water was sampled, filtered through a 0.45-mm PES syringe filter (Millipore), and then acidified with $\mathrm{HNO}_{3} \mathrm{sp}$ at $1 \% \mathrm{v} / \mathrm{v}$ for dissolved $\mathrm{Pb}$ concentrations analysis (ICP-MS). Physicochemical characteristics of river water were taken from the Agence de l'Eau de Seine-Normandie public database for sites sampled in 2008 and 2009 (http://www.eau-seine-normandie.fr/). For the other sites, $1 \mathrm{~mL}$ of raw water was sampled and analysed by chromatographic analysis [Dionex DX120, column IonPac CS16 Dionex N057573 (4 x $250 \mathrm{~mm}$ )] for $\mathrm{Ca}^{2+}, \mathrm{Na}^{+}$ and $\mathrm{Mg}^{2+}$ concentrations determination. The digestion method and analysis of the organisms were successfully validated by the reference material (CMR Mussel Tissue ERM-CE278) and the analysis of the media waters was validated with natural water certified reference material (NIST 1640). Reference materials results were within the certified $95 \%$ confidence limit range for $\mathrm{Pb}$.

\subsection{Kinetic modelling and parameter estimation}

\subsubsection{Theory and assumptions}

In the present study, we only focused on $\mathrm{Pb}$ uptake and accumulation from solution, ignoring any trophic uptake of $\mathrm{Pb}$ by the amphipods. Since no significant growth of organisms has been observed during the 12- $\mathrm{d}$ of experiment, metal bioaccumulation from solution can be expressed according to the first-order kinetic model as follows:

$\frac{d C_{\text {metal }}}{d t}=k_{\text {in }} \cdot C_{w}-k_{\text {out }} \cdot C_{\text {metal }}$

where $C_{\text {metal }}$ is the metal concentration accumulated in organisms $\left(\mathrm{mg} \mathrm{g}^{-1}\right), \mathrm{C}_{\mathrm{w}}$ is the dissolved concentration of $\mathrm{Pb}$ in the column water $\left(\mathrm{mg} \mathrm{L}^{-1}\right)$, and $k_{\text {in }}$ and $k_{\text {out }}$ the kinetic parameters that are, respectively, the uptake rate constant $\left(\mathrm{L} \mathrm{g}^{-1} \mathrm{~d}^{-1}\right)$ and the elimination rate constant $\left(\mathrm{d}^{-1}\right)$. These kinetic parameters are specific to each metal/organism couple and they are generally assumed to be independent of $C_{w}$ (Luoma and Rainbow, 2005). Moreover, $\mathrm{C}_{\mathrm{w}}$ is assumed to be constant during the exposure.

The integration of Eq. (1) characterises metal accumulation as follows:

$C_{\text {metal }}=\frac{k_{\text {in }} \cdot C_{w}}{k_{\text {out }}}\left(1-e^{-k_{\text {out }} t}\right)$

Under the assumption of steady-state achievement at the end of the exposure, metal bioaccumulation from the solution ( $t \rightarrow \infty$ ) is expressed as follows:

$C_{s S}=\frac{k_{\text {in }} \cdot C_{w}}{k_{\text {out }}}$

with $\mathrm{C}_{\mathrm{ss}}$, the concentration of metal in organisms in the steady state $\left(\mathrm{mg} \mathrm{g}^{-1}\right)$.

At the end of the exposure phase, organisms are introduced for the depuration phase into uncontaminated microcosms where $C_{w}$ is null. In these conditions, Eq. (1) is reduced to:

$\frac{d C_{\text {metal }}}{d t}=-k_{\text {out }} \cdot C_{\text {metal }}$

The integration of Eq. (4) characterises metal elimination as follows:

$C_{\text {metal }}=C_{\text {metal }}(0) \cdot e^{-k_{\text {out }} \cdot t}$

where $C_{\text {metal }}(0)$ is the concentration of metal in organisms at the beginning of the depuration phase $\left(\mu \mathrm{g} \mathrm{g}^{-1}\right)$. 


\subsubsection{Fitting to laboratory data}

The kinetic model was fitted to $\mathrm{Pb}$ concentrations in organisms for both the exposure and the depuration phases together, since Eq. (2) (exposure) and Eq. (5) (depuration) share the parameter $k_{\text {out }}$. All the Pb exposure conditions $\left(1,2.5,5,10,25,50\right.$, and $\left.100 \mu \mathrm{g} \mathrm{L}^{-1}\right)$ were considered simultaneously, and to check the independence of $k_{\text {in }}$ and $k_{\text {out }}$ from $\mathrm{C}_{\mathrm{w}}$, two models were built: one model where kinetic parameters $k_{\text {in }}$ and $k_{\text {out }}$ were concentration-specific (model \#1, 2*7 = 14 parameters in total), and one simpler model where $k_{\text {in }}$ and $k_{\text {out }}$ were concentration-independent, i.e., kinetic parameters are common to all exposure conditions (model \#2, two parameters in total). Model \#1 and model \#2 were compared based on their AIC (Akaike (1981) information criterion), which provides a means for model selection by the trade-off between the goodness of fit and the complexity of the model. This enabled us to determine whether kinetic parameters are concentration-specific (model \#1) or can be considered as concentration-independent (model \#2). Models were fitted to the data by nonlinear least square regression. Data were scaled (divided by the exposure concentration) to ensure a constant variance of data across exposure concentrations.

\subsubsection{Modelling the influence of major ions on Pb uptake}

According to Bourgeault et al. (2010), the effects of ions on metal uptake can be explicitly taken into account with the model. This requires the use of a competition model in which the uptake rate constant is related to the concentrations of the ions considered and the affinity constants of the ions for their biological binding sites and is expressed as follows:

$k_{\text {in }}=k_{\text {in } \max } /\left(1+\sum_{i} \frac{C_{i}}{K i_{C i}}\right)$

where $k_{\text {in max }}$ is the uptake rate constant of the metal in the absence of the considered ions in water, $C_{i}$ is the concentrations of ions in the media water, and $K i_{C i}$ is the affinity constant that represents the ion concentration required to divide by two the metal uptake rate constant. The weaker the affinity constant, the stronger the competition effect.

The fit by nonlinear regression of Eq. (6) on the $k_{\text {in }}$ dataset given by varying ionic concentrations in the

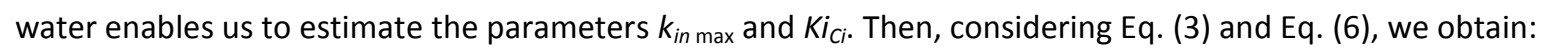

$C_{S S}=\frac{k_{\text {in } \max } /\left(1+\sum_{i} \frac{C_{i}}{\overline{K i}_{C i}}\right)}{k_{\text {out }}} \cdot C_{w}$

\subsubsection{Estimations toward in situ conditions}

In this study, the suitability of the model to estimate bioaccumulation of $\mathrm{Pb}$ in gammarids under realistic environmental conditions was investigated. To this end, bioaccumulation was predicted with (1) the bioaccumulation model expressed by Eq. (3) using the experimentally determined kin and kout and the dissolved $\mathrm{Pb}$ concentrations ( $\mathrm{CW}$ ) measured in situ and (2) the bioaccumulation model integrating additionally the effect of cations (Eq. (7)) using the experimentally determined kin max, $\mathrm{KiCi}$ and kout and the dissolved $\mathrm{Pb}$ concentrations $(\mathrm{CW})$ and ion concentrations $(\mathrm{Ci})$ measured in situ. Then predictions were compared with bioaccumulations observed in collected native gammarids. The match of the predictions with the observations was calculated using an indicator of goodness of fit, the scaled root mean square error:

$S R M S E=\frac{100}{\overline{\text { observations }}} \times \sqrt{\frac{1}{n} \times \sum_{i=1}^{n}\left(\text { estimation }_{i}-\text { observation }_{i}\right)^{2}}$

where observation ${ }_{i}=$ observed internal $\mathrm{Pb}$ concentrations at site $\mathrm{i}$, estimation $_{i}=$ modelled $\mathrm{Pb}$ contents in gammarids at site $i, \mathrm{n}=$ total number of observations, and $\overline{\text { observations }}=$ mean of all the observed $\mathrm{Pb}$ contents in gammarids. The lower the SRMSE, the better the model estimation. 


\subsubsection{Statistical analysis}

Nonlinear regressions and AIC calculations were performed using R (R Core Team, 2012) and the 'nlstools' package (Baty et al., Accepted). Estimates of parameters $k_{i n}, k_{\text {in } \max } K i_{C a}$ and $k_{\text {out }}$ are given with a confidence interval of $95 \%$. Nonparametric Kruskal-Wallis tests were used to compare $\mathrm{Pb}$ concentrations after 5 days in exposed versus control gammarids as well as $\mathrm{Pb}$ concentrations after 2 days in gammarids exposed to $\mathrm{Pb}$ with versus without $\mathrm{Ca}^{2+}, \mathrm{Na}^{+}$or $\mathrm{Mg}^{2+}$. The background level of $\mathrm{Pb}$ in gammarids at the beginning of the exposure phase is given as mean \pm standard deviation.

\section{Results and discussion \\ 3.1. Kinetic parameters}

After five days of experiment, exposed gammarids significantly accumulated $\mathrm{Pb}$ compared to the control gammarids (Kruskal-Wallis, $p<0.05$ ). The accumulation and depuration kinetics obtained for each group of exposed gammarids are depicted in Fig. 2. Pb accumulation increased linearly in the first $24 \mathrm{~h}$ and started to slow down from the second day, finally tending towards the achievement of a steady-state until the end of the exposure phase. These results are in agreement with the efficient metal accumulation capacities of $G$. pulex already observed for $\mathrm{Cd}, \mathrm{Ni}, \mathrm{Cu}$, and $\mathrm{Zn}$ (Lebrun et al., 2011, 2012; Pellet et al., 2009; Vellinger et al., 2012; Xu and Pascoe, 1993). Dedourge-Geffard et al. (2009) and Besse et al. (2013) also reported the ability of another closely related species, Gammarus fossarum, to accumulate metals during in situ experiments. Thus, the genus Gammarus is currently proposed as a promising candidate for monitoring water quality (Besse et al., 2013; Clason et al., 2004; Fialkowski et al., 2003; Xu and Pascoe, 1994).

During the depuration phase, $\mathrm{Pb}$ was exponentially excreted leading to body concentrations in gammarids reaching the background level within 9 days, which showed that excretion mechanisms are favoured rather than storage strategies.

The kinetic model was fitted to $\mathrm{Pb}$ concentrations in organisms for both exposure and depuration phases together in order to estimate the kinetic parameters kin and kout. The results of the AIC score calculation showed that the AIC score for model \#1 was greater than the AIC score for model \#2, which confirms that kinetic parameters were concentration-independent leading to the following global kinetic parameters:

$k_{\text {in }}=1.01 \mathrm{~L} \mathrm{~g}^{-1} \mathrm{~d}^{-1}[0.88 ; 1.14]$ and $k_{\text {out }}=0.33 \mathrm{~d}^{-1}[0.28 ; 038]$.

The uptake rate constant for $\mathrm{Pb}\left(k_{i n}\right)$ was similar to the uptake rate constants reported in H. azteca and $D$. magna, equal to $1.5 \mathrm{~L} \mathrm{~g}^{-1} \mathrm{~d}^{-1}$ and $1.2 \mathrm{~L} \mathrm{~g}^{-1} \mathrm{~d}^{-1}$ respectively (Komjarova and Blust, 2008; MacLean et al., 1996). The $k_{\text {in }}$ value was also in the same order of magnitude as the $k_{\text {in }}$ value reported in G. pulex for Cd $\left(0.46 \mathrm{~L} \mathrm{~g}^{-1} \mathrm{~d}^{-1}\right)$ by Pellet et $a l$. (2009), which suggests that $\mathrm{Pb}$ and $\mathrm{Cd}$ have similar affinity to biological binding sites. This analogy may be justified by the implication of similar biological pathways as reported by Macdonald et al. (2002).

The elimination rate constant of $\mathrm{Pb}$ determined in $G$. pulex was close to the one established in another freshwater amphipod $H$. azteca, with a value of $0.52 \mathrm{~d}^{-1}$ (MacLean et al., 1996), suggesting a similar $\mathrm{Pb}$ excretion capacities. Moreover, G. pulex seems to have similar abilities to excrete $\mathrm{Pb}$ and $\mathrm{Ni}$ since their kout values are in the same order of magnitude, respectively 0.33 and $0.13 \mathrm{~d}^{-1}$ (Lebrun et $a l ., 2011$ ). On the contrary, the elimination rate constant of $\mathrm{Pb}$ was about 10 times higher than the one of $\mathrm{Cd}$ of $0.032 \mathrm{~d}^{-1}$ (Pellet et al., 2009), which suggests that different excretion mechanisms occurred. 

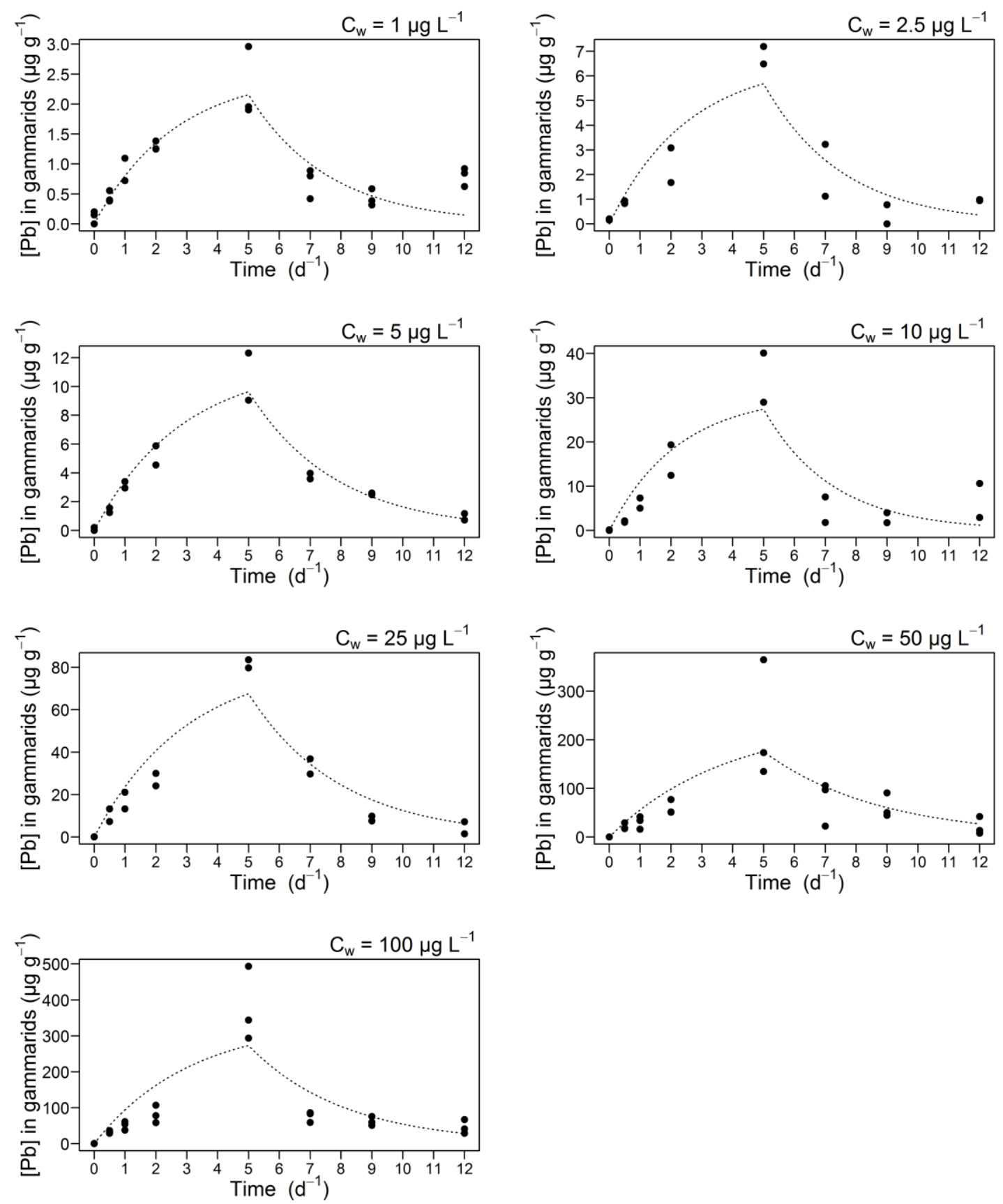

Fig. 2. Accumulation and depuration kinetics of $\mathrm{Pb}$ in $\mathrm{G}$. pulex for each exposure condition $\left(C_{w}\right)$. Black points are replicates each composed by a pool of 5 gammarids and dotted lines represent the best model fit of Eq. (2) (exposure phase) and Eq. (5) (depuration phase) on the $\mathrm{Pb}$ contents in gammarids.

\subsection{Influence of water cationic composition on Pb uptake}

Neither $\mathrm{Mg}^{2+}$ nor $\mathrm{Na}^{+}$had a significant effect on $\mathrm{Pb}$ uptake $(p=0.92$ and 0.74 , respectively, Kruskal-Wallis, data not shown). Inversely, the $k_{\text {in }}$ value for $\mathrm{Pb}$ decreased from 1.25 to $0.34 \mathrm{~L} \mathrm{~g}^{-1} \mathrm{~d}^{-1}$ with increasing Ca concentrations from 11.5 (initial content in the mineral water) to $154 \mathrm{mg} \mathrm{L}^{-1}$ (Fig. 3). In D. magna, Komjarova and Blust (2009) showed that the $\mathrm{Pb}$ uptake doubled with high sodium content (184 $\mathrm{mg} \mathrm{L}^{-1}$ ) and sharply decreased with a high $\mathrm{Ca}^{2+}$ concentration $\left(100 \mathrm{mg} \mathrm{L}^{-1}\right.$ ) (Komjarova and Blust, 2009). It is well known that some trace metals are able to enter cells via routes for the uptake of major metal ions (Rainbow, 1997). Previous studies in fish have demonstrated that $\mathrm{Pb}$ is preferentially taken up via $\mathrm{Ca}^{2+}$ channels and consequently 
competes with $\mathrm{Ca}^{2+}$ for penetration into organisms (Macdonald et al., 2002; Niyogi and Wood, 2004; Rogers et al., 2003; Rogers and Wood, 2004).

Derived from Eq. (6), the effect of $\mathrm{Ca}^{2+}$ concentration observed on $k_{\text {in }}$ value is given by:

$k_{\text {in }}=k_{\text {in } \max } /\left(1+\frac{C_{C a}}{K i_{C a}}\right)$

where the model parameters were estimated at the following values: $k_{\text {in } \max }=1.38 \mathrm{~L} \mathrm{~g}^{-1} \mathrm{~d}^{-1}[1.00 ; 1.76]$ and $K i_{C a}=60 \mathrm{mg} \mathrm{L}^{-1}$ [18: 101]. The model is shown in Fig. 3. Thus, accounting for the effect of only $\mathrm{Ca}^{2+}$, bioaccumulation of metal from the solution in the steady-state ( $\rightarrow \infty$ ) (Eq. (7)) is expressed as follows:

$C_{S S}=\frac{k_{\text {in } \max } /\left(1+\frac{C_{C a}}{K i_{C a}}\right)}{k_{\text {out }}} \cdot C_{w}$

In G. pulex, the effect of $\mathrm{Ca}^{2+}$ has also been observed for $\mathrm{Cd}$ with a $\mathrm{Ki}_{\mathrm{Ca}}=66.4 \mathrm{mg} \mathrm{L}^{-1}$ and for $\mathrm{Ni}$ with an affinity constant equal to $181.5 \mathrm{mg} \mathrm{L}^{-1}$ (Lebrun et al., 2011; Pellet et al., 2009). The similarity between the affinity constants of $\mathrm{Pb}$ and $\mathrm{Cd}$ underlined the comparable behaviour of these two metals to enter biological surfaces and especially the use of the same entry pathway via $\mathrm{Ca}^{2+}$ channels as reported for $\mathrm{Cd}$ in bivalves or in freshwater snails (Croteau and Luoma, 2007; Qiu et al., 2005). Moreover, Pb uptake in G. pulex probably does not involve $\mathrm{Na}^{+}$or $\mathrm{Mg}^{2+}$ channels, as indicated by the $\mathrm{Na}^{+}$and $\mathrm{Mg}^{2+}$ concentrations having no effect on the $k_{\text {in }}$ value.

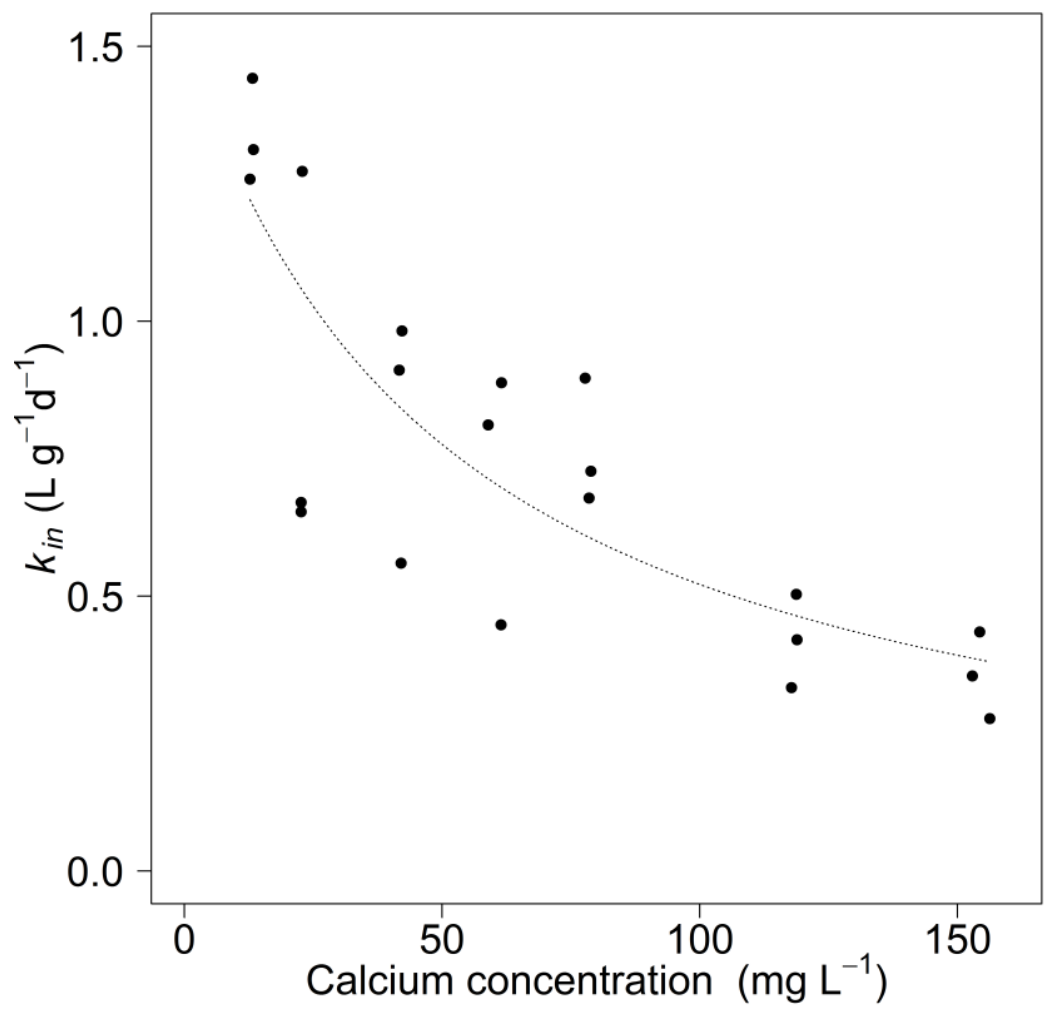

Fig. 3. Inhibition of the $\mathrm{Pb}$ uptake by increasing $\mathrm{Ca}^{2+}$ concentrations in $\mathrm{G}$. pulex exposed to $10 \mathrm{mg} \mathrm{L}^{-1} \mathrm{~Pb}$. The dashed line represents the best fit of a competitive model (Eq. (6)) to data. Points are replicates each composed by a pool of 5 gammarids. 


\subsection{In situ model validation}

Our field study aimed to assess whether experimentally-derived kinetic parameters could be suitable to estimate $\mathrm{Pb}$ contents in native gammarids. Samples of native gammarids in 21 sites were collected from the Seine watershed on which $\mathrm{Pb}$ contents were measured. Assuming that in situ organisms are in equilibrium with their medium, waterborne $\mathrm{Pb}$ bioaccumulation at steady state was calculated with a kinetic model calibrated in the laboratory taking into account or not the effect of calcium. As presented in Table 1, concentrations of dissolved $\mathrm{Pb}$ in the 21 sites ranged between 0.03 and $1.60 \mathrm{mg} \mathrm{L}^{-1}$, only two sites exhibited $\mathrm{Pb}$ concentrations higher than the related recent EQS (1.2 $\mathrm{mg} \mathrm{L}^{-1}$ (Directive, 2013/39/EC)). Pb contents in native gammarids ranged between 0.84 and $3.43 \mu \mathrm{g} \mathrm{g}^{-1}$, i.e., above the background concentration observed in $\mathrm{G}$. pulex used to calibrate the model in the laboratory $\left(0.64 \mu \mathrm{g} \mathrm{g}^{-1}\right.$ ) (Table 1). Clason et al. (2004) reported comparable $\mathrm{Pb}$ concentrations measured in Gammarus oceanicus of up to $2 \mu \mathrm{g} \mathrm{g}^{-1}$ in northern Norway. Calcium profiles were contrasted with a minimum concentration of $47 \mathrm{mg} \mathrm{L}^{-1}$ and a maximum of $159 \mathrm{mg} \mathrm{L}^{-1}$ (Table 1), which is consistent with the limestone geology of the Seine watershed.

\section{Table 1}

Summary of the dissolved contamination levels of $\mathrm{Pb}$ in waters $\left(\mathrm{mg} \mathrm{L}^{-1}\right), \mathrm{Pb}$ concentrations in native gammarids $\left(\mu \mathrm{g} \mathrm{g}^{-1}\right)$ and concentrations of the major cations $\mathrm{Ca}^{2+}, \mathrm{Mg}^{2+}$ and $\mathrm{Na}^{+}\left(\mathrm{mg} \mathrm{L}^{-1}\right)$ at the 21 sampling sites for which bioaccumulation was predicted by the kinetic model.

\begin{tabular}{|c|c|c|c|c|c|c|}
\hline \multicolumn{2}{|c|}{ Sampling sites } & \multicolumn{5}{|l|}{ Measured concentrations } \\
\hline Year & River & $\mathrm{Pb}$ in gammarids $\left(\mu \mathrm{g} \mathrm{g}^{-1}\right)$ & dissolved $\mathrm{Pb}\left(\mu \mathrm{g} \mathrm{L}^{-1}\right)$ & $\mathrm{Ca}^{2+}\left(\mathrm{mg} \mathrm{L}^{-1}\right)$ & $\mathrm{Mg}^{2+}\left(\mathrm{mg} \mathrm{L}^{-1}\right)$ & $\mathrm{Na}^{+}\left(\mathrm{mg} \mathrm{L}^{-1}\right)$ \\
\hline 2008 & Le Lieutel & 1.21 & 0.64 & 119 & 23 & 34 \\
\hline 2008 & L'Essonne & 3.12 & 0.51 & 117 & 5 & 47 \\
\hline 2008 & La Sausseron & 1.49 & 0.29 & 116 & 20 & 12 \\
\hline 2008 & La Juine & 1.96 & 0.11 & 104 & 4 & 9 \\
\hline 2008 & La Gondoire & 1.75 & 0.12 & 114 & 10 & 21 \\
\hline 2008 & La Rimarde & 0.84 & 0.06 & 113 & 4 & 13 \\
\hline 2008 & L'Ecole & 1.05 & 0.08 & 114 & 4 & 17 \\
\hline 2008 & Ru de Senneville & 0.90 & 0.47 & 120 & 17 & 15 \\
\hline 2008 & La Mauldre & 2.93 & 0.83 & 116 & 18 & 63 \\
\hline 2008 & Ru d'Ancueil & 1.03 & 0.08 & 153 & 8 & 75 \\
\hline 2008 & Ru de Gally & 3.43 & 1.60 & 118 & 12 & 61 \\
\hline 2008 & L'Oeuf & 0.98 & 0.03 & 120 & 5 & 8 \\
\hline 2008 & L'Epte & 1.60 & 0.15 & 120 & 5 & 20 \\
\hline 2008 & La Levrière & 2.06 & 1.10 & 122 & 8 & 10 \\
\hline 2009 & L'Essonne & 2.31 & 1.60 & 124 & 7 & 47 \\
\hline 2009 & Ru de Fourville & 1.19 & 0.37 & 120 & 20 & 14 \\
\hline 2009 & La Sausseron & 1.14 & 0.53 & 120 & 20 & 14 \\
\hline 2012 & Le Rognon & 0.92 & 0.06 & 47 & 3 & 4 \\
\hline 2012 & L'Auve & 0.84 & 0.05 & 130 & 2 & 8 \\
\hline 2013 & Ru de Gally & 1.64 & 0.51 & 159 & 19 & 77 \\
\hline 2013 & Le Rognon & 1.10 & 0.26 & 98 & 8 & 16 \\
\hline
\end{tabular}

Fig. 4A displays the observed bioaccumulation levels compared with the estimated bioaccumulation levels calculated with Eq. (3) using $k_{\text {in }}$ and $k_{\text {out }}$ of $1.01 \mathrm{~L} \mathrm{~g}^{-1} \mathrm{~d}^{-1}$ and $0.33 \mathrm{~d}^{-1}$. Results show a good agreement between observations and estimations, with $85 \%$ of the estimations between the dashed lines representing a twofold deviation above or below the theoretical 1:1 relationship. The calculated SRMSE was equal to $71 \%$. Overall, $15 \%$ of the points were above the dashed line, which means that bioaccumulated concentrations were overestimated at those sites. These results suggest that other factors could influence the metal uptake, typically calcium concentrations. Besides, the kinetic model assumes that the concentrations to which organisms are exposed are constant. However, although the metal exposure can be easily verified in the laboratory, it is sometimes not certain in situ because of the temporal fluctuations of the contamination that may occur during particular incidents such as accidental discharge, floods or flushing. Thus, a single measure of the dissolved metal concentration in situ could introduce a bias in the estimated bioaccumulation and may explain some discrepancies between predictions and observations. Fig. $4 \mathrm{~B}$ depicts the observed bioaccumulation levels compared with the estimated bioaccumulation levels taking into account the effect of $\mathrm{Ca}^{2+}$. Bioaccumulated concentration was calculated with Eq. (10) with $k_{\text {in } \max }=1.38 \mathrm{~L} \mathrm{~g}^{-1} \mathrm{~d}^{-1}, k_{\text {out }}=0.33 \mathrm{~d}^{-1}, K i_{C a}=$ 
$60 \mathrm{mg} \mathrm{L}^{-1}$, experimentally derived in the laboratory for this study and the lead concentration $C_{w}$ and the calcium concentration $\mathrm{C}_{\mathrm{Ca}}$ measured at the sampling site. The consideration of $\mathrm{Ca}^{2+}$ resulted in a tightening of the plot around the theoretical 1:1 relationship. The calculated SRMSE was equal to $40 \%$, which means that the consideration of $\mathrm{Ca}^{2+}$ improves the estimation accuracy by about $44 \%$. Thus, calcium concentrations in the ambient water seem to be an important factor influencing bioaccumulation of $\mathrm{Pb}$ since the consideration of the effect of calcium has permitted to improve bioaccumulation modelling.

As presented in Fig. 4B, the model taking into account $\mathrm{Ca}^{2+}$ concentrations under-estimates the bioaccumulation in $14 \%$ of the cases. The sites for which the bioaccumulation was underestimated were not geographically close and no other factors than those given in Table 1 were available to support any explanation. These observations may be related to a lower impact of $\mathrm{Ca}^{2+}$ concentrations under field conditions as compared with observed effects under laboratory conditions. Another explanation could be the contribution of the trophic route at these sites. In the literature, an increasing number of studies have found that, for particular metal/ species combinations, diet is an important contributory factor in metal bioaccumulation, and the contribution of the trophic route needs to be integrated to improve the accuracy of any biodynamic model. This is, for example, the case of $\mathrm{Cd}, \mathrm{Zn}$ or $\mathrm{Ag}$ in the marine lugworm, Arenicola marina (Casado-Martinez et al., 2009) or in marine and freshwater bivalves (Luoma and Rainbow, 2005). To date, bioaccumulation data of $\mathrm{Pb}$ are limited in freshwater species and the question of the contribution of the trophic route is yet not univocal. Thus, studies assessing the dietary route of $\mathrm{Pb}$ in gammarids will bring complementary information to the limited body of literature concerning dietary route of $\mathrm{Pb}$ in aquatic organisms.

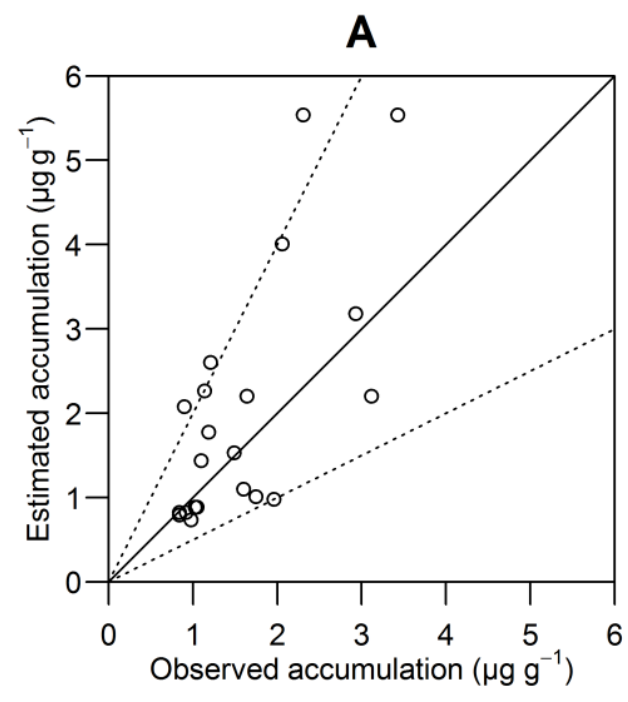

B

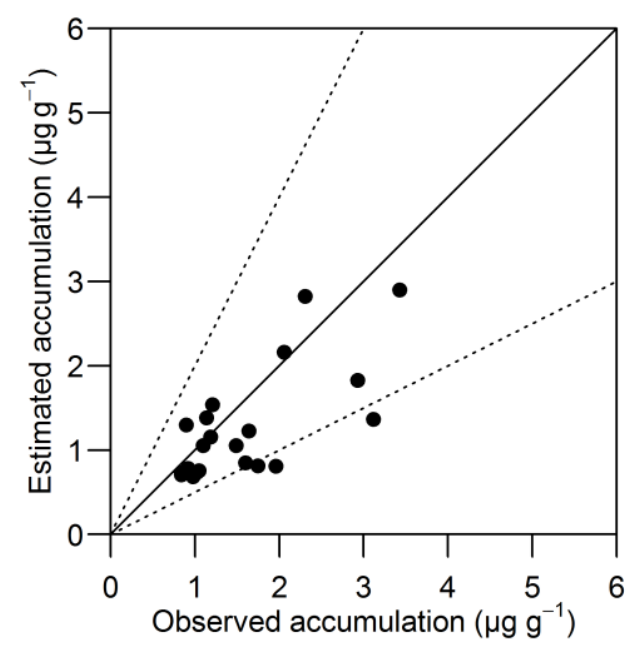

Fig. 4. Observed bioaccumulation levels of $\mathrm{Pb}$ in native gammarids against estimated bioaccumulation levels by the kinetic model using Eq. (3) $\left(k_{\text {in }}=1.01 \mathrm{~L} \mathrm{~g}^{-1} \mathrm{~d}^{-1}\right.$ and $k_{\text {out }}=0.33$ $\mathrm{d}^{-1}$, established in the Volvic $^{\circledR}$ mineral water containing a basal $\mathrm{Ca}^{2+}$ concentration of 11.5 $\left.\mathrm{mg} \mathrm{L}^{-1}\right)$ for the plot $\mathrm{A}$ and using Eq. (10) $\left(k_{\text {in } \max }\right.$ $=1.38 \mathrm{~L} \mathrm{~g}^{-1} \mathrm{~d}^{-1}$ and $k_{\text {out }}=0.33 \mathrm{~d}^{-1}$ and $K i_{C a}=60$ $\mathrm{mg} \mathrm{L}^{-1}$ ) for the plot $B$ (white and black symbols are mean values, $n=3$ pools of 5 gammarids). The solid line represents the theoretical model fit 1:1 and dashed lines display a deviation of 2-fold above and below the relationship 1:1. 
In this study, the experimentally derived kinetic parameters were highly applicable to environmental conditions encountered in the Seine watershed, in spite of ignoring the dietary route of uptake. In the perspective to tend towards the use of a generalised model to predict $\mathrm{Pb}$ bioaccumulation, it could be opportune to validate the kinetic parameters over a larger geographical scale and in contrasted hydrosystems (variability of size, metal contamination, geochemical parameters...). However, the validation of the model can be limited because they cannot be tested if native gammarids are absent. To overcome this issue, the use of transplanted organisms can be relevant. Indeed, this approach allows for studies at sites devoid of native gammarids. Moreover, the use of transplanted organisms limits biological variability, which can hinder the interpretation of bioaccumulation, as organisms are collected from the same population (Besse et al., 2012, 2013; Bourgeault et al., 2010; Mersch et al., 1996). This approach also enables control of the exposure during the transplantation period, and facilitates robust inter-site comparisons (Besse et al., 2012). Therefore, in further studies, the use of transplanted gammarids could be an interesting approach to assess the performances of the model at large spatial scales.

\section{Conclusion}

An experimentally-derived kinetic model was used to predict waterborne bioaccumulation of $\mathrm{Pb}$ in native populations of $G$. pulex from the Seine watershed. Results showed a relatively robust agreement between the predicted and measured bioaccumulation levels, highlighting the applicability of the kinetic parameters for $G$. pulex to environmental conditions. The results of the present study also demonstrate that the use of dissolved metal concentrations allows for accurate predictions of $\mathrm{Pb}$ accumulation in $\mathrm{G}$. pulex. Moreover, the consideration of the effect of calcium concentrations into the model has improved $\mathrm{Pb}$ bioaccumulation modelling. This supports that water chemistry needs to be taken into account when interpreting field data of bioaccumulation in this species. Finally, the relevance of the model was successful in the environmental conditions presented in this study. Through the use of transplanted gammarids in large geographical scale, the application of a generalised predictive model will be assessed in further investigations.

\section{Acknowledgments}

The authors are sincerely grateful to Adeline Francois, Aurélie Germain and Pauline Robert-Sainte for their active contribution and to the DRIEE ILE-DE-FRANCE (Direction Régionale et Interdépartementale de I'Environnement et de l'Energie) for its involvement during the sampling campaigns. We also wish to thank Sophie Ayrault for providing access to the ICP-MS platform at LSCE. We thank the PIREN-Seine research program, the AESN (BioMarqulndic program) and the Ile-de-France Regional Council (R2DS program) for its financial support. The authors wish to thank Pierre Brigode for his help to produce map and figures with the $R$ software. We are grateful to the anonymous reviewers for their constructive comments.

\section{References}

Akaike, H., 1981. Likelihood of a model and information criteria. J. Econom. 1, 3-14.

Baty, F., Ritz, C., Charles, S., Brutsche, M., Flandrois, J.P., Delignette-Muller, M.-L., 2014. A Toolbox for Nonlinear Regression in R: The Package nlstools. Accepted for Publication at the Journal of Statistical Software.

Baudrimont, M., Andrès, S., Metivaud, J., Lapaquellerie, Y., Ribeyre, F., Maillet, N., Latouche, C., Boudou, A., 1999. Field transplantation of the freshwater bivalve Corbicula fluminea along a polymetallic contamination gradient (river Lot, France): II. Metallothionein response to metal exposure. Environ. Toxicol. Chem. 18, 2472-2477.

Berglin, R., Dave, G., Sjöbeck, M.-L., 1985. The effects of lead on $\delta$-aminolevulinic acid dehydratase activity, growth, hemoglobin content, and reproduction in Daphnia magna. Ecotoxicol. Environ. Saf. 9, 216-229. 
Besse, J.-P., Coquery, M., Lopes, C., Chaumot, A., Budzinski, H., Labadie, P., Geffard, O., 2013. Caged Gammarus fossarum (Crustacea) as a robust tool for the characterization of bioavailable contamination levels in continental waters: Towards the determination of threshold values. Water Res. 47, 650-660. doi:10.1016/j.watres.2012.10.024

Besse, J.-P., Geffard, O., Coquery, M., 2012. Relevance and applicability of active biomonitoring in continental waters under the Water Framework Directive. TrAC Trends Anal. Chem. 36, 113-127.

Besser, J.M., Brumbaugh, W.G., Brunson, E.L., Ingersoll, C.G., 2005. Acute and chronic toxicity of lead in water and diet to the amphipod Hyalella azteca. Environ. Toxicol. Chem. SETAC 24, 1807-1815.

Bourgeault, A., Gourlay-Francé, C., Tusseau-Vuillemin, M.-H., 2010. Modeling the effect of water chemistry on the bioaccumulation of waterborne cadmium in zebra mussels. Environ. Toxicol. Chem. 29, 2182-2189.

Casado-Martinez, M.C., Smith, B.D., DelValls, T.A., Luoma, S.N., Rainbow, P.S., 2009. Biodynamic modelling and the prediction of accumulated trace metal concentrations in the polychaete Arenicola marina. Environ. Pollut. 157, $2743-2750$. doi:10.1016/j.envpol.2009.04.032

Chevreuil, M., Blanchard, M., Teil, M.-J., Carru, A.-M., Testard, P., Chesterikoff, A., 1996. Evaluation of the pollution by organochlorinated compounds (polychlorobiphenyls and pesticides) and metals ( $\mathrm{Cd}, \mathrm{Cr}, \mathrm{Cu}$ and $\mathrm{Pb}$ ) in the water and in the zebra mussel (Dreissena polymorpha pallas) of the river Seine. Water. Air. Soil Pollut. 88, 371-381. doi:10.1007/BF00294112

Clason, B., Gulliksen, B., Zauke, G.-P., 2004. Assessment of two-compartment models as predictive tools for the bioaccumulation of trace metals in the amphipod Gammarus oceanicus Segerstrale, 1947 from Grunnfjord (Northern Norway). Sci. Total Environ. 323, 227-241.

Cresswell, T., Simpson, S.L., Smith, R.E.W., Nugegoda, D., Mazumder, D., Twining, J., 2014. Bioaccumulation and retention kinetics of cadmium in the freshwater decapod Macrobrachium australiense. Aquat. Toxicol. 148, 174-183. doi:10.1016/j.aquatox.2014.01.006

Croteau, M.-N., Luoma, S.N., 2007. Characterizing dissolved $\mathrm{Cu}$ and $\mathrm{Cd}$ uptake in terms of the biotic ligand and biodynamics using enriched stable isotopes. Environ. Sci. Technol. 41, 3140-3145.

Dedourge-Geffard, O., Palais, F., Biagianti-Risbourg, S., Geffard, O., Geffard, A., 2009. Effects of metals on feeding rate and digestive enzymes in Gammarus fossarum: An in situ experiment. Chemosphere 77, $1569-1576$. doi:10.1016/j.chemosphere.2009.09.042

Directive, 2000/60/EC of the European parliament and of the council of 23 October 2000 establishing a framework for Community action in the field of water policy, Official Journal of European Communities.

Directive, 2008/105/EC of the european parliament and of the council of 16 December 2008 on environmental quality standards in the field of water policy, amending and subsequently repealing Council Directives 82/176/EEC, 83/513/EEC, 84/156/EEC, 84/491/EEC, 86/280/EEC and amending Directive 2000/60/EC of the European Parliament and of the Council, Official Journal of European Communities.

Directive, 2013/39/EC of the European parliament and of the council of 12 August 2013 amending Directives 2000/60/EC and 2008/105/EC as regards priority substances in the field of water policy, Official Journal of European Communities.

Di Toro, D.M., Allen, H.E., Bergman, H.L., Meyer, J.S., Paquin, P.R., Santore, R.C., 2001. Biotic ligand model of the acute toxicity of metals. 1. Technical basis. Environ. Toxicol. Chem. 20, 2383-2396.

Felten, V., Charmantier, G., Mons, R., Geffard, A., Rousselle, P., Coquery, M., Garric, J., Geffard, O., 2008. Physiological and behavioural responses of Gammarus pulex (Crustacea: Amphipoda) exposed to cadmium. Aquat. Toxicol. 86, 413-425. doi:10.1016/j.aquatox.2007.12.002

Fialkowski, W., Fialkowska, E., Smith, B.D., Rainbow, P.S., 2003. Biomonitoring survey of trace metal pollution in streams of a catchment draining a zinc and lead mining area of Upper Silesia, Poland using the amphipod Gammarus fossarum. Int. Rev. Hydrobiol. 88, 187-200.

Fialkowski, W., Rainbow, P.S., 2006. The discriminatory power of two biomonitors of trace metal bioavailabilities in freshwater streams. Water Res. 40, 1805-1810. 
Forrow, D.M., Maltby, L., 2000. Toward a mechanistic understanding of contaminant-induced changes in detritus processing in streams: Direct and indirect effects on detritivore feeding. Environ. Toxicol. Chem. 19, 2100-2106.

Gaillardet, J., Viers, J., Dupré, B., 2003. Trace elements in river waters. Treatise Geochem. 5, 225-272.

Graça, M.A.S., Cressa, C., Gessner, T.M.O., Feio, M.J., Callies, K.A., Barrios, C., 2001. Food quality, feeding preferences, survival and growth of shredders from temperate and tropical streams. Freshw. Biol. 46, 947-957.

Grosell, M., Gerdes, R., Brix, K.V., 2006. Influence of Ca, humic acid and pH on lead accumulation and toxicity in the fathead minnow during prolonged water-borne lead exposure. Comp. Biochem. Physiol. Part C Toxicol. Pharmacol. 143, 473-483.

Holcombe, G.W., Benoit, D.A., Leonard, E.N., McKim, J.M., 1976. Long-term effects of lead exposure on three generations of brook trout (Salvelinus fontinalis). J. Fish. Board Can. 33, 1731-1741.

Kalman, J., Smith, B.D., Riba, I., Blasco, J., Rainbow, P.S., 2010. Biodynamic modelling of the accumulation of Ag, Cd and Zn by the deposit-feeding polychaete Nereis diversicolor: Inter-population variability and a generalised predictive model. Mar. Environ. Res. 69, 363-373. doi:10.1016/j.marenvres.2010.01.001

Keithly, J., Brooker, J.A., Deforest, D.K., Wu, B.K., Bríx, K.V., 2004. Acute and chronic toxicity of nickel to a cladoceran (Ceriodaphnia dubia) and an amphipod (Hyalella azteca). Environ. Toxicol. Chem. 23, 691-696.

Kienle, C., Köhler, H.-R., Gerhardt, A., 2009. Behavioural and developmental toxicity of chlorpyrifos and nickel chloride to zebrafish (Danio rerio) embryos and larvae. Ecotoxicol. Environ. Saf. 72, 1740-1747.

Komjarova, I., Blust, R., 2009. Effect of $\mathrm{Na}, \mathrm{Ca}$ and $\mathrm{pH}$ on simultaneous uptake of $\mathrm{Cd}, \mathrm{Cu}, \mathrm{Ni}, \mathrm{Pb}$, and $\mathrm{Zn}$ in the water flea Daphnia magna measured using stable isotopes. Aquat. Toxicol. 94, 81-86. doi:10.1016/j.aquatox.2009.05.018

Komjarova, I., Blust, R., 2008. Multi-metal interactions between $\mathrm{Cd}, \mathrm{Cu}, \mathrm{Ni}, \mathrm{Pb}$ and $\mathrm{Zn}$ in water flea Daphnia magna, a stable isotope experiment. Aquat. Toxicol. 90, 138-144. doi:10.1016/j.aquatox.2008.08.007

Kutlu, M., Düzen, A., Bayçu, C., Özata, A., 2002. A transmission electron microscope investigation of the effect of lead acetate on the hepatopancreatic ceca of Gammarus pulex. Environ. Toxicol. Pharmacol. 12, 181-187.

Lebrun, J.D., Perret, M., Geffard, A., Gourlay-Francé, C., 2012. Modelling copper bioaccumulation in Gammarus pulex and alterations of digestive metabolism. Ecotoxicology 21, 2022-2030.

Lebrun, J.D., Perret, M., Uher, E., Tusseau-Vuillemin, M.-H., Gourlay-Francé, C., 2011. Waterborne nickel bioaccumulation in Gammarus pulex: Comparison of mechanistic models and influence of water cationic composition. Aquat. Toxicol. 104, 161-167. doi:10.1016/j.aquatox.2011.04.011

Lebrun, J.D., Uher, E., Tusseau-Vuillemin, M.-H., Gourlay-Francé, C., 2014. Essential metal contents in indigenous gammarids related to exposure levels at the river basin scale: Metal-dependent models of bioaccumulation and geochemical correlations. Sci. Total Environ. 466, 100-108.

Luoma, S.N., Rainbow, P.S., 2005. Why Is Metal Bioaccumulation So Variable? Biodynamics as a Unifying Concept. Environ. Sci. Technol. 39, 1921-1931. doi:10.1021/es048947e

Macdonald, A., Silk, L., Schwartz, M., Playle, R.C., 2002. A lead-gill binding model to predict acute lead toxicity to rainbow trout (Oncorhynchus mykiss). Comp. Biochem. Physiol. Part C Toxicol. Pharmacol. 133, 227-242. doi:10.1016/S15320456(02)00107-2

MacLean, R.S., Borgmann, U., Dixon, D.G., 1996. Bioaccumulation kinetics and toxicity of lead in (Hyalella azteca)(Crustacea, Amphipoda). Can. J. Fish. Aquat. Sci. 53, 2212-2220.

Mersch, J., Wagner, P., Pihan, J.-C., 1996. Copper in indigenous and transplanted zebra mussels in relation to changing water concentrations and body weight. Environ. Toxicol. Chem. 15, 886-893. doi:10.1002/etc.5620150610

Morel, F.M.M., 1983. Principles of aquatic chemistry, 1983. Wiley: New York.

Niyogi, S., Wood, C.M., 2004. Biotic ligand model, a flexible tool for developing site-specific water quality guidelines for metals. Environ. Sci. Technol. 38, 6177-6192. 
Pellet, B., Ayrault, S., Tusseau-Vuillemin, M.-H., Gourlay-Francé, C., 2014. Quantifying diet-borne metal uptake in Gammarus pulex using stable isotope tracers. Ecotoxicol. Environ. Saf. 110, 182-189. doi:10.1016/j.ecoenv.2014.09.001

Pellet, B., Geffard, O., Lacour, C., Kermoal, T., Gourlay-Francé, C., Tusseau-Vuillemin, M.-H., 2009. A model predicting waterborne cadmium bioaccumulation in Gammarus pulex: the effects of dissolved organic ligands, calcium, and temperature. Environ. Toxicol. Chem. 28, 2434-2442.

Pyatt, A., Pyatt, F., Pentreath, V., 2002. Lead toxicity, locomotion and feeding in the freshwater snail, Lymnaea stagnalis (L.). Invert. Neurosci. 4, 135-140.

Qiu, J.-W., Xie, Z.-C., Wang, W.-X., 2005. Effects of calcium on the uptake and elimination of cadmium and zinc in Asiatic clams. Arch. Environ. Contam. Toxicol. 48, 278-287.

R Core Team 2012., R: A language and environment for statistical computing. R Foundation for Statistical Computing, Vienna, Austria. ISBN 3-900051-07-0, URL http://www.R-project.org/.

Rainbow, P.S., 1997. Ecophysiology of trace metal uptake in crustaceans. Estuar. Coast. Shelf Sci. 44, 169-175.

Rogers, J.T., Richards, J.G., Wood, C.M., 2003. Ionoregulatory disruption as the acute toxic mechanism for lead in the rainbow trout (Oncorhynchus mykiss). Aquat. Toxicol. 64, 215-234.

Rogers, J.T., Wood, C.M., 2004. Characterization of branchial lead-calcium interaction in the freshwater rainbow trout Oncorhynchus mykiss. J. Exp. Biol. 207, 813-825.

Ruby, S.M., Hull, R., Anderson, P., 2000. Sublethal lead affects pituitary function of rainbow trout during exogenous vitellogenesis. Arch. Environ. Contam. Toxicol. 38, 46-51.

Slaveykova, V.I., Wilkinson, K.J., 2002. Physicochemical aspects of lead bioaccumulation by Chlorella vulgaris. Environ. Sci. Technol. 36, 969-975.

Tan, Q.-G., Wang, W.-X., 2008. The influences of ambient and body calcium on cadmium and zinc accumulation in Daphnia magna. Environ. Toxicol. Chem. SETAC 27, 1605-1613.

Tusseau-Vuillemin, M.-H., Gourlay, C., Lorgeoux, C., Mouchel, J.-M., Buzier, R., Gilbin, R., Seidel, J.-L., Elbaz-Poulichet, F., 2007. Dissolved and bioavailable contaminants in the Seine river basin. Sci. Total Environ. 375, 244-256.

Vellinger, C., Parant, M., Rousselle, P., Immel, F., Wagner, P., Usseglio-Polatera, P., 2012. Comparison of arsenate and cadmium toxicity in a freshwater amphipod (Gammarus pulex). Environ. Pollut. 160, 66-73. doi:10.1016/j.envpol.2011.09.002

Welton, J.S., 1979. Life-history and production of the amphipod Gammarus pulex in a Dorset chalk stream. Freshw. Biol. 9 , 263-275.

WHO, 1995. WHO, International programme on chemical safety, environmental health criteria, Genève, 1995.

Xu, Q., Pascoe, D., 1994. The importance of food and water as sources of zinc during exposure of Gammarus pulex (Amphipoda). Arch. Environ. Contam. Toxicol. 26, 459-465.

Xu, Q., Pascoe, D., 1993. The bioconcentration of zinc by Gammarus pulex (L.) and the application of a kinetic model to determine bioconcentration factors. Water Res. 27, 1683-1688. doi:10.1016/0043-1354(93)90132-2 